\title{
NATURAL WEATHERING PERFORMANCE OF THERMALLY TREATED POPLAR AND BLACK PINE WOOD
}

\author{
Vasiliki Kamperidou ${ }^{1, \star}$ \\ https://orcid.org/0000-0003-3276-9394
}

Ioannis Barboutis ${ }^{1}$

\begin{abstract}
The wood of poplar (Populus sp.) and black pine (Pinus nigra) species was subjected to thermal treatment under variant conditions of temperature, $180{ }^{\circ} \mathrm{C}$ and $200{ }^{\circ} \mathrm{C}$, and duration of $3 \mathrm{~h}, 5 \mathrm{~h}, 7 \mathrm{~h}$, and its resistance to natural weathering was investigated through the determination of crucial properties, such as the colour and surface roughness, while the appearance of the boards was assessed both visually and through a microscope, prior to and after their exposure outdoors. Prior to the outdoors exposure, it was observed that, as the intensity of heat treatment increases, wood tends to darken, with the parallel decrease of $L^{*}$ index, referring to the tangential, radial and cross-sectional surface of both species specimens. The surface roughness of both wood species was found to decrease only in the boards of the mildest treatment, while as the treatment intensity increases, the roughness degree demonstrated a strong increase compared to unmodified wood. After the 100-day exposure of poplar and pine boards to external conditions, they acquired a wilder look and new checks and cracks emerged in the boards surface, while fungi infestation signs appeared, most apparent in control and boards treated at milder treatments, with modified poplar boards to demonstrate more dense defects patterns on their surfaces, compared to modified black pine boards. A similar degree of discoloration recorded on unmodified boards was observed also on the thermally modified boards, which was except for the visual assessment, confirmed by the recorded progress of $L^{*}, a^{*}$ and $b^{*}$ colour indexes of poplar and pine surfaces and is probably attributed to leaching of the water soluble extractives. The roughness of all of the exposed boards surfaces was found higher than the respective values recorded prior to the exposure and among the treated boards only those of the milder treatments presented lower roughness values than the unmodified ones. Thermal treatment enhanced the biological durability and dimensional stability of both species, but it did not adequately protect the wood from the weathering effect when it was exposed outdoors. Nevertheless, wood modified at short-term heat treatments exhibited enhanced properties compared to unmodified wood and taking into account that the milder treatments did not cause mechanical strength loss, these materials could be utilized in applications where structures are not continually and directly exposed to aging factors, such as under shelter applications, or after the application of a thermal and surface modification with protective preservatives combination.
\end{abstract}

Keywords: Colour, pine, poplar, surface roughness, thermal modification, weathering.

\section{INTRODUCTION}

Although timber is proven to be advantageous construction material, it is characterized by some disadvantages, inherent to its hygroscopic nature. The hygroscopicity of wood is related to the alterations in wood dimensions, due to changes in the air humidity, which cause difficulties to its application in structures, especially if the anisotropy of wood is taken also into consideration. Furthermore, wood is susceptible 
to micro-organisms action and changes in appearance and decomposition after exposure to environmental conditions, where degradation factors prevail, such as the solar UV factor, changes in temperature, relative humidity, rain, snow and, air. The long-term effects of these factors cause the phenomenon of "weathering" of wood, which is macroscopic observations involves color change, appearance of cracks, distortions, surface roughness and surface corrosion of wood, while the effect of climatic factors seems to be even more apparent on the tangential than the radial surface of wood (Ates et al. 2010). Solar radiation, especially the ultraviolet one, in combination with humidity, temperature and oxygen of the atmosphere, results in various physicochemical effects such as a decrease in the degree of polymerization of cellulose, breakage of chemical bonds, intercellular layer among others, and reduction of mechanical strength. It is believed that the degradation of wood, resulting from its aging, is mainly attributed to the disruption of the cell walls lignin network in the surface of wood, which creates surface irregularities and favorable conditions for the growth and catastrophic action of fungi, microfungi, bacteria and insects that consequently cause the mechanical strength deterioration (Rajković and Miklečić 2012).

The exposure of wood to heat treatment is one of the simplest, easiest, of low cost and energy consumption and ecological methods of wood modification that seems to eliminate these drawbacks of wood (Ates et al. 2010) and has been developed in Europe during the last decades using mainly wood species of low natural durability (Mburu et al. 2008). The process of thermal modification creates a physically, chemically and mechanically "new" material, usually characterized by improved dimensional stability (Bak and Nemeth 2012), increased biological resistance against fungi and microorganisms attacks, lower equilibrium moisture content (EMC) and density, reduced wettability, electrical resistance, and emissions of volatile organic compounds, improved resistance to natural weathering, enhancement of colour uniformity and stability (Awoyemi et al. 2009). Although the color stability and uniformity of wood are improved by thermal treatment, when the wood is exposed to external conditions, chromophores of thermally modified wood, that are unstable to sunlight, usually provide a shade between gray and white to the surface, but to a less extent than unmodified wood (Rajković and Miklečić 2012). Feist and Sell (1987) modified thermally at $175^{\circ} \mathrm{C}$ $195{ }^{\circ} \mathrm{C}$ beech and fir wood and recorded increased resistance of beech wood to aging factors, whereas no particular improvement in weathering resistance of fir, attributed this difference to the fact that softwoods cellulose decomposes at lower temperatures $\left(150^{\circ} \mathrm{C}\right.$ and above) than that of the hardwoods.

Thermal treatment seems to decrease the surface roughness of wood (Schneid et al. 2014), even in the case of quite low temperatures $\left(150{ }^{\circ} \mathrm{C}\right.$ ) (Gündüz et al. 2008). Nevertheless, Budakci et al. (2013) recorded an increase in surface roughness of wood after its thermal treatment, which is mainly attributed to the hemicelluloses degradation, loss of mass and decrease in density. Therefore, the effect of thermal treatment on the roughness of wood is not very clear. Parallel, in the previous studies, it is not clear if the roughness measurements have been carried out on machined and modified, modified and machined, or modified and finished/sanded wood specimens, which would help the results to be comparable and safe conclusions to be drawn. Additionally, no comprehensive information has been detected so far on the roughness of thermally treated wood after its outdoors exposure.

In the current work, the wood species of poplar and black pine were subjected to thermal treatment under variant conditions and its resistance to natural weathering was investigated through the determination of crucial fortheirutilization properties, suchas colour, surfaceroughness, whilethemacroscopicand microscopic assessment of appearance and structure of the boards was implemented, prior to and after their 100-day exposure to outdoor conditions, in order to comprehend the response of thermally treated wood on natural weathering process.

\section{Materials and methods}

In the specific research, poplar (hybrid: Populus sp.) wood of a tree coming from the plantation, obtained from a sawmill in Drama region (North Greece), and black pine (Pinus nigra L.) wood, obtained from a sawmill in Kalambaka region (central Greece), were used as raw material. One stem per species was cut parallel to the grain, preparing boards that were placed for about 8 months in an air-conditioned room at a temperature of $20{ }^{\circ} \mathrm{C} \pm 2{ }^{\circ} \mathrm{C}$ and $60 \% \pm 5 \%$ relative humidity and left there till a constant weight, recording the EMC of 10,50 \% for poplar and 11,44 \% for pine wood (ISO 13061-1 (2014)). The mean density (mass/ volume, measured with moisture content at the reported levels) of poplar was $0,385 \mathrm{~g} / \mathrm{cm}^{3}$ and of pine was $0,662 \mathrm{~g} / \mathrm{cm}^{3}$ (presenting dense structure with thin annual rings) ISO 13061-2 (2014). The dimensions of the boards prior to the treatment were $35 \mathrm{~mm}$ thick (tangential surface), $70 \mathrm{~mm}$ wide (radial surface), $400 \mathrm{~mm}$ in length, with their length to be in a direction parallel to the grain, while they consisted mainly of sapwood part, and the sampling method was based on the methodology of ISO 3129 (2019). 10 boards per species, poplar and 
pine, were subjected to each of the different thermal modification treatments.

\section{Thermal treatments}

The treatment of the boards was carried out in a laboratory drying chamber $(800 \mathrm{~mm}$ x $500 \mathrm{~mm} \times$ $600 \mathrm{~mm}$ ), at $180{ }^{\circ} \mathrm{C}$ and $200{ }^{\circ} \mathrm{C}$ under atmospheric pressure in the presence of air. The moisture content of the boards was $10,5 \%$ and $11,44 \%$ and for poplar and black pine wood, respectively, when placed in the chamber, which was preheated to the final temperature. In each treatment, 10 identical planed, but non-sanded boards were placed into the chamber in specific places of equal distance from the chamber walls and from one another, in order to ensure the uninterrupted movement of the air between the boards. The treatment duration of $3 \mathrm{~h}, 5 \mathrm{~h}$ and, $7 \mathrm{~h}$ were applied, counting $15 \mathrm{~min}$ more for the recovery of the temperature in the chamber. The specific durations were selected as they differentiate from the existing literature of thermal treatment processes, providing new data, and were selected to be shorter than the respective durations used industrially, since the oxygen atmosphere of the chamber could cause faster thermal degradation of wood components (Yildiz et al. 2011). The chamber atmosphere of oxygen was chosen as part of a thermal treatment method of high simplicity in equipment, low cost and energy consumption that could be easily applied by smaller wood industries. After thermal treatment, the boards were placed into large desiccators to return gradually to ambient conditions, and stacked in an air-conditioned room at constant conditions $\left(60 \% \pm 5 \%, 20^{\circ} \mathrm{C} \pm 2{ }^{\circ} \mathrm{C}\right)$. Only defect-free material was used in the tests. The present study investigates only the resistance of the modified materials to weathering factors, but since it constitutes a part of experimental work, other critical properties of the materials, such as their physical (EMC, density, biological durability among others), hygroscopic (tangential and radial swelling, adsorption) and mechanical properties (static bending strength, modulus of elasticity, impact bending strength, hardness, compression strength among others) have already been investigated (Kamperidou and Barboutis 2017, Kamperidou and Barboutis 2018, Kamperidou et al. 2013, Kamperidou 2019).

\section{Weathering tests}

The dimensions of the boards of both species were $300 \mathrm{~mm}$ x $35 \mathrm{~mm}$ x $70 \mathrm{~mm}$ and all the surfaces, except for the radial ones intended to be exposed to aging factors and examined, were coated with a single-component polyurethane adhesive, to limit the moisture absorption rate, according to CEN EN 927-3 (2019). The boards were planed to be smooth and uniform. The radial surfaces of the boards were chosen to be exposed, since they are less susceptible to weathering, than the tangential ones (Sandberg 1999), but usually of higher roughness because of the structure of wood and the pattern of annual rings and the alternation between earlywood and latewood. 3 boards for each species and each material category (treated and untreated) were then fastened on frames, placed on metal constructions inclined at a $45^{\circ}$ angle, in a way that moisture could not be withheld, and exposed to the roof of our Department building outdoors, oriented in south direction (Thessaloniki, North Greece), for approximately 3,5 months (100 days), in a period from September till the mid- December. The distance of the lowest specimen from the ground was $1050 \mathrm{~mm}$, while the space beneath the fastened boards remained vacant to avoid moisture retention (Figure 1a).

Prior to and after the 100-day exposure of the boards, the color, surface roughness and anatomical characteristics were examined on the board radial surfaces, to compare their resistance to weathering. A visual assessment of the boards for the detection of defects was carried out, rating the intensity or the number of defects on a scale from 0 (unchanged, no defects) to 5 (severe changes, dense pattern of defects) (ISO 4628-1 2016).

\section{Anatomical characteristics and structure}

The macroscopic and microscopic characteristics of the radial wood surface of the unmodified and modified boards were examined prior to and after the outdoors exposure, in the specified circle areas, using an electron microscope SM with an X16 analysis (Figure 1b). 


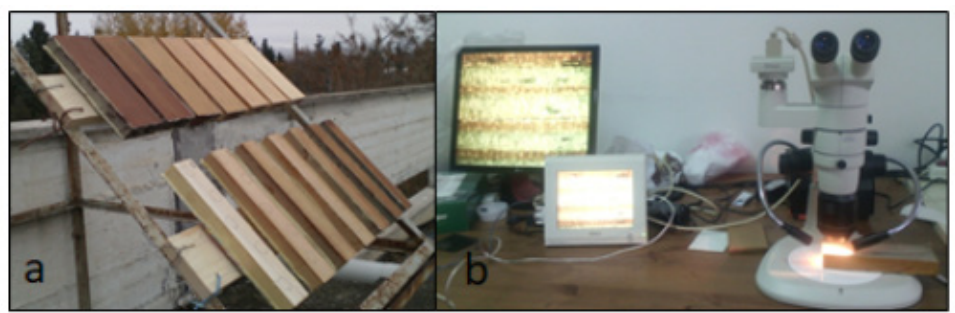

Figure 1: Placement of specimens at an angle of $45^{\circ}$ to check the (a) physical resistance to outdoor weathering, (b) Stereoscope Nikon SMZ800 electronic stereoscope.

\section{Color change due to weathering}

The color was measured on the radial surface of all the boards, prior to and after the exposure to outdoors conditions. The measurements were implemented, after the process of mild sanding, using a Minolta (Chroma-Meter CR-300 Colourimeter) colorimeter (Figure 2a). The sensor head diameter was $6 \mathrm{~mm}$ and a 10 -degree observer was used. The reflectance rate was at $10 \mathrm{~nm}$ intervals on the visible spectrum (from $400 \mathrm{~nm}$ to $700 \mathrm{~nm}$ ), which were converted to CIELAB color system coordinates (DIN EN ISO 11664-3 (2012)). The color was defined and compared, using a system of three color coordinates, called CIE $L^{*} a^{*} b^{*}$, according to the CIE standard, based on a D65 light source. Approximately 10-15 measurements were taken at 5 different circle points on the radial surface of the boards for each category of wood (control and modified material) (Figure 2b). In both species, the color differences between sapwood-heartwood or caused by the presence of annual rings were considered to be negligible.

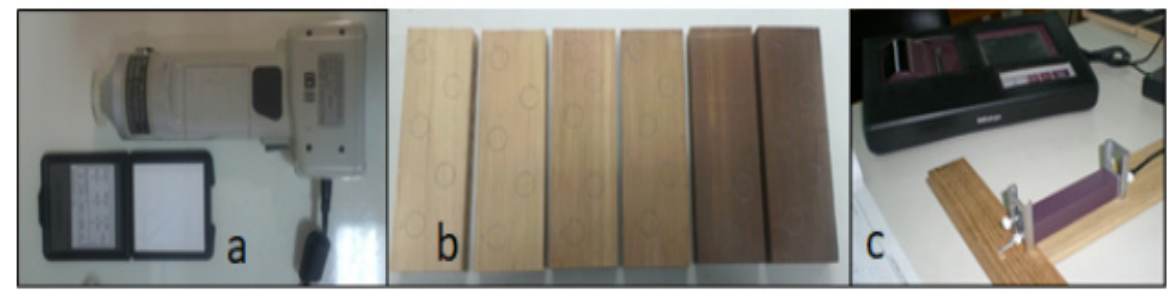

Figure 2: (a) Colorimeter Minolta Chroma-Meter CR-300, (b) circle points of measurements on pine boards, (c) roughness testing with a profilometer device.

These three color coordinates, $L^{*}, a^{*}$, and $b^{*}$, were recorded through the colorimeter and the values of the color coordinates were used to calculate the parameter called 'Total Color Difference $\Delta E$ ', the parameter 'Chroma $C^{*}$ ' and the parameter 'Saturation $\Delta C^{*}$ ' (ASTM D2244-16 2016, DIN EN ISO 11664-3 2012).

\section{Surface roughness tests}

The surface roughness of the boards was determined using a profilometer (Mitutoyo Surftest SJ-301) following the profile method with the device's diamond stylus (Figure 2c). The measuring speed, the diameter of the pin and the top angle of the pin tool were $10 \mathrm{~mm} / \mathrm{min}, 4 \mu \mathrm{m}$, and $90^{\circ}$, respectively. Roughness index values were determined within $\pm 0,01 \mu \mathrm{m}$.

Roughness measurement points were randomly selected by marking them on the radial surface of the samples. Measurements were implemented perpendicular to the fiber direction of the specimen. The three roughness parameters, the mean arithmetic deviation of profile $(R a)$, the mean peak-to-valley height $(R z)$, and the root mean square deviation of the assessed profile $(R q)$ (ISO 4287 1997) were chosen to be determined, since they are widely used in the evaluation of surface roughness of wood and wood products (Stumbo 1963, Mummery 1992). Prior to each measurement, the apparatus was calibrated and the measurements were carried out under ambient conditions. Two days before the measurements, the radial surface of all the boards was 
planed and sanded with a head-turning machine that bears 180-degree sandpaper, to ensure the reliability of the results (Korkut and Budakci 2010). Roughness testing was performed on the radial surface of the boards, which typically exhibits lower roughness (Budakci et al. 2013). Approximately 15 roughness values were obtained from the boards of each treated material category.

SPSS Statistics PASW 18 statistical package was used for statistical analysis and processing of the results. The Least Significant Difference two way Analysis of Variance (LSD-Two-way ANOVA) method was used in the results, which examines the effect of two different independent variables (temperature and duration), but also the effect of any interaction between these two factors upon the dependent variable (color, roughness, among others).

\section{RESULTS AND DISCUSSION}

\section{Anatomical characteristics and structure}

\section{Poplar}

Before and at the end of the 100-day exposure of the boards to external conditions, the boards were examined macroscopically and microscopically to detect any differences in the appearance of wood (Figure 3, Figure 4, Figure 5). In general, a similar degree of discoloration (gray) of the control boards was observed compared to that of the thermally modified boards, probably due to the leaching of the water-soluble extracts, and the gradual photochemical and oxidative reactions that are accelerated mainly by the factors of UV-light and moisture (Yildiz et al. 2011). This color alteration recorded on the exposed radial surfaces was in any case uniformly distributed throughout the board surface (control and modified boards). In addition, after the exposure, the wood became rough, new checks appeared on the surface, the checks created by the heat treatment were converted into cracks (especially in the boards of more intense treatments, e.g. $200{ }^{\circ} \mathrm{C}-5 \mathrm{~h}$ and $7 \mathrm{~h}$ ) and signs of fungal infestation and mildew colonizing (black spots, to a great extent in the control, but to a less extent also in the boards of milder treatments). Of particular importance is the existence of stretch marks mentioned because the wood is left unprotected against the destructive action of wood-destroying insects and fungi. Characteristic is the large difference in fungal infestation between the control pine boards that bear strongly the signs of infestation and the thermally modified pine specimens, where almost no signs of infestation were recorded (Figure 9). Therefore, heat treatment contributed only to a small extent to the resistance of poplar or pine against the climatic factors that cause aging, regardless of temperature or duration of heat treatment.

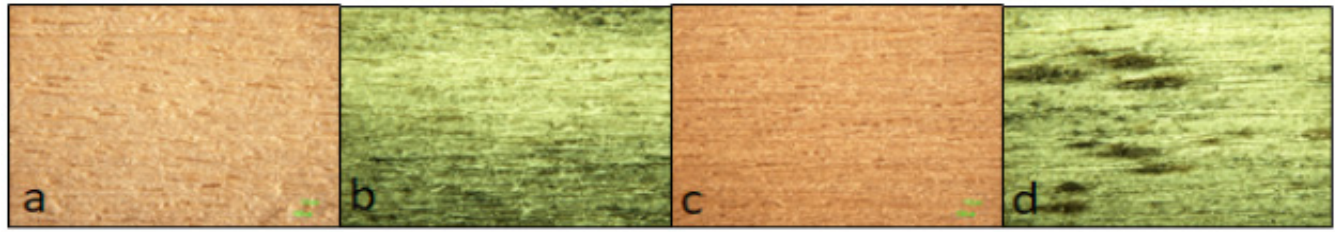

Figure 3: View of unmodified poplar board, before (a) and after (b) the 100-day outdoors exposure, thermally modified poplar board point $\left(180^{\circ} \mathrm{C}-3 \mathrm{~h}\right)$, before (c) and after (d) the exposure outdoors.

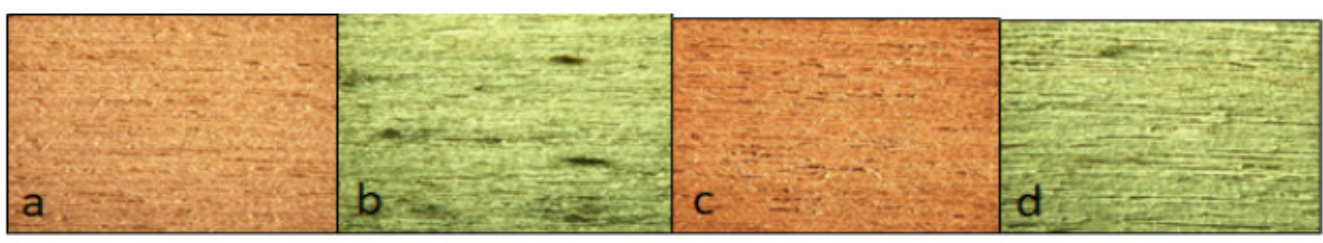

Figure 4: View of thermally modified poplar board $\left(180^{\circ} \mathrm{C}-7 \mathrm{~h}\right)$ before (a) and after (b) the 100-day outdoors exposure, thermally modified poplar $\left(200^{\circ} \mathrm{C}-7 \mathrm{~h}\right)$ before $(\mathrm{c})$ and after $(\mathrm{d})$ the exposure outdoors.

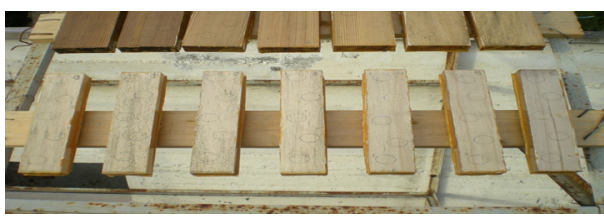

Figure 5: Poplar boards after a 100-day outdoors exposure (from the left to the right: control and the treatments: $180{ }^{\circ} \mathrm{C}-3 \mathrm{~h}, 180{ }^{\circ} \mathrm{C}-5 \mathrm{~h}, 180{ }^{\circ} \mathrm{C}-7 \mathrm{~h}, 200{ }^{\circ} \mathrm{C}-3 \mathrm{~h}, 200^{\circ} \mathrm{C}-5 \mathrm{~h}, 200{ }^{\circ} \mathrm{C}-7 \mathrm{~h}$ ). 


\section{Black Pine}

When the pine wood was exposed to external conditions, its appearance changed significantly, compared to the pre-exposure examination, which is attributed first of all to the apparent color change. This change is caused mainly by the chromophores of thermally modified wood that are unstable to sunlight that give a shade of gray and white to the wood surface, almost to the same extent as the unmodified wood, as well as the hemicellulose degradation that results in higher rates of lignin in wood mass (Kamperidou et al. 2013) and lignin condensation (Garcia et al. 2014). Significant differences were recorded between the appearance of unmodified and modified pine wood boards (Figure 6, Figure 7, Figure 8), with the control board presenting a dense pattern of defects after the exposure outdoors and thermally treated boards to present much less dense defects pattern. Thermally treated poplar wood surfaces presented a denser pattern of defects (Figure 9).

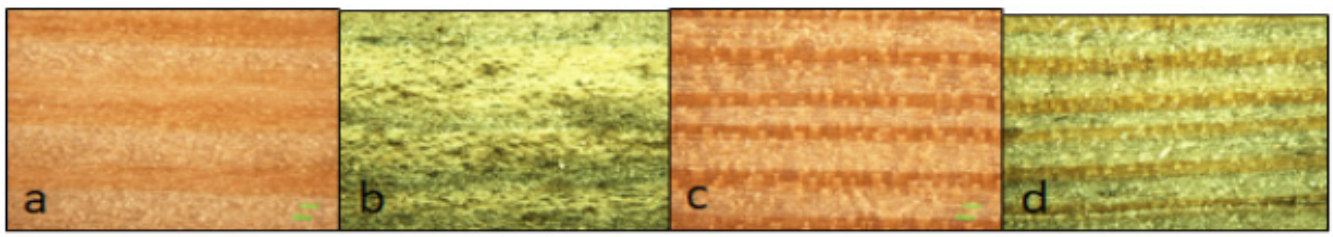

Figure 6: Unmodified black pine board point (a) and after (b) the 100-day outdoors exposure, thermally modified black pine board $\left(180^{\circ} \mathrm{C}-3 \mathrm{~h}\right)$, before (c) and after (d) the exposure outdoors.

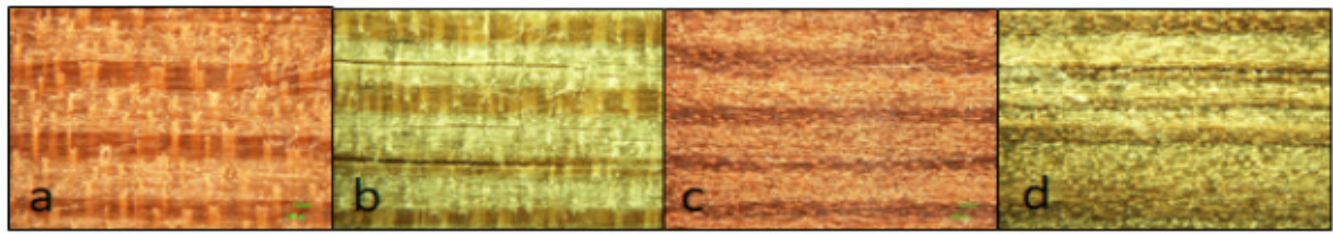

Figure 7: Thermally modified black pine board point $\left(180^{\circ} \mathrm{C}-7 \mathrm{~h}\right)$, before (a) and after (b) the exposure outdoors, modified black pine $\left(200^{\circ} \mathrm{C}-7 \mathrm{~h}\right)$, before (c) and after (d) the exposure.

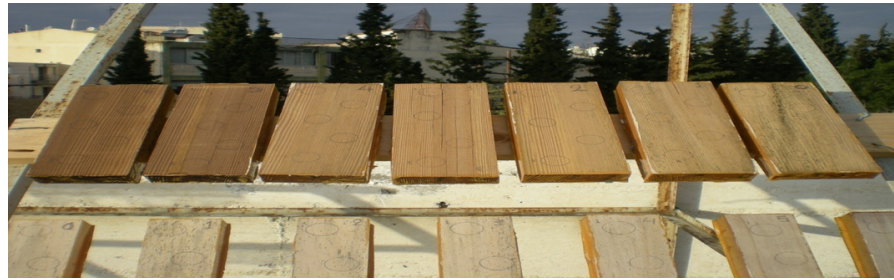

Figure 8: View of black pine boards after the 100-day exposure outdoors (from right to left: control and the treatments: $180^{\circ} \mathrm{C}-3 \mathrm{~h}, 180{ }^{\circ} \mathrm{C}-5 \mathrm{~h}, 180{ }^{\circ} \mathrm{C}-7 \mathrm{~h}, 200{ }^{\circ} \mathrm{C}-3 \mathrm{~h}, 200{ }^{\circ} \mathrm{C}-5 \mathrm{~h}, 200{ }^{\circ} \mathrm{C}-7 \mathrm{~h}$ ).

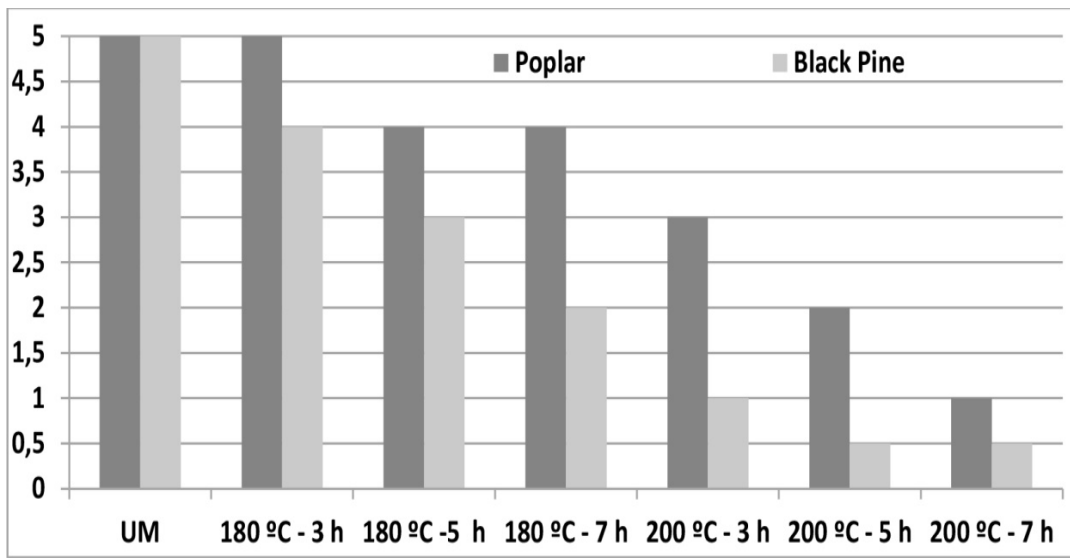

Figure 9: Evaluation results of the intensity and quantity of defects on a rating scale from 0 (unchanged, no defects) to 5 (severe changes, dense pattern of defects) (axe Y) on the unmodified (UM) and modified (180

${ }^{\circ} \mathrm{C}-3 \mathrm{~h}, 180{ }^{\circ} \mathrm{C}-5 \mathrm{~h}, 180{ }^{\circ} \mathrm{C}-7 \mathrm{~h}, 200{ }^{\circ} \mathrm{C}-3 \mathrm{~h}, 200{ }^{\circ} \mathrm{C}-5 \mathrm{~h}, 200{ }^{\circ} \mathrm{C}-7 \mathrm{~h}$ ) boards surfaces. 


\section{Color change after outdoors exposure}

\section{Poplar}

The results reveal that although prior to the exposure the boards had obvious color differences with each other due to thermal treatments, after the 100-day exposure, the boards were discolored to such an extent that eventually all boards had a similar color to that of the control. This is also evident in the diagrams showing the course of the color indexes $L^{*}, a^{*}$ and $b^{*}$ on the surface of poplar (Table 1, Table 2) and pine (Table 3, Table 4) specimens after the exposure. This fact reveals that heat treatment, irrespectively of duration or temperature, failed to protect the color of the boards from discoloration caused by climatic factors.

Table 1: Mean values of color parameters $\left(L^{*}, a^{*}, b^{*}\right)$ on the surface of thermally modified and unmodified (UM) poplar boards, before and after exposure to outdoor conditions.

\begin{tabular}{|c|c|c|c|c|c|c|}
\hline \multirow{2}{*}{ Treatment } & \multicolumn{3}{|c|}{ Before exposure } & \multicolumn{3}{c|}{ After a 100 - day exposure } \\
\cline { 2 - 7 } & $L^{*}$ & $a^{*}$ & $b^{*}$ & $L^{*}$ & $a^{*}$ & $b^{*}$ \\
\hline $\mathrm{UM}$ & $80,40(1,91)$ & $3,58(0,42)$ & $17,58(1,68)$ & $68,98(2,34)$ & $1,56(0,38)$ & $10,16(0,58)$ \\
\hline $180^{\circ} \mathrm{C}-3 \mathrm{~h}$ & $72,80(1,03)$ & $5,64(0,44)$ & $23,76(0,68)$ & $65,45(1,48)$ & $1,46(0,11)$ & $9,60(0,37)$ \\
\hline $180^{\circ} \mathrm{C}-5 \mathrm{~h}$ & $65,09(0,80)$ & $7,08(0,29)$ & $25,55(1,17)$ & $68,29(3,50)$ & $1,56(0,36)$ & $9,11(0,55)$ \\
\hline $180^{\circ} \mathrm{C}-7 \mathrm{~h}$ & $67,49(1,12)$ & $6,96(0,35)$ & $25,33(1,14)$ & $70,58(3,20)$ & $1,76(0,42)$ & $9,99(0,62)$ \\
\hline $200^{\circ} \mathrm{C}-3 \mathrm{~h}$ & $56,31(1,93)$ & $7,99(0,32)$ & $23,79(0,46)$ & $66,92(3,22)$ & $1,51(0,36)$ & $9,50(0,57)$ \\
\hline $200^{\circ} \mathrm{C}-5 \mathrm{~h}$ & $50,00(1,74)$ & $8,56(0,17)$ & $22,47(1,16)$ & $66,17(1,52)$ & $1,55(0,14)$ & $8,87(0,35)$ \\
\hline $200^{\circ} \mathrm{C}-7 \mathrm{~h}$ & $44,83(1,95)$ & $8,42(0,38)$ & $19,72(1,56)$ & $68,84(1,74)$ & $2,06(0,12)$ & $9,10(0,36)$ \\
\hline
\end{tabular}

Standard deviation values in parentheses.

According to the statistical analysis, $L^{*}$ values did not present any statistical differences one another, except for the value of the most intensive treatment $\left(200{ }^{\circ} \mathrm{C}-7 \mathrm{~h}\right)$, which differs from all the other categories respective values. The values of $a^{*}$ did not differ statistically significantly from each other. The $b^{*}$ values also did not differ statistically significantly from each other, except for the value of control that differs from the two most intensive treatments $\left(200{ }^{\circ} \mathrm{C}-5 \mathrm{~h}\right.$ and $\left.7 \mathrm{~h}\right)$, as well as between the values of treatments $180{ }^{\circ} \mathrm{C}-5 \mathrm{~h}$ and treatments of $200{ }^{\circ} \mathrm{C}$.

Table 2: Mean color change values on surfaces of thermally modified and unmodified (UM) poplar boards after 100 - day outdoors exposure.

\begin{tabular}{|c|c|c|c|c|c|c}
\hline \multirow{2}{*}{ Treatment } & \multicolumn{3}{|c|}{ Before Exposure } & \multicolumn{3}{c}{ After 100 days of exposure } \\
\cline { 2 - 7 } & $L^{*}$ & $a^{*}$ & $b^{*}$ & $L^{*}$ & $a^{*}$ & $b^{*}$ \\
\hline $\mathrm{UM}$ & $78,06(0,31)$ & $5,50(0,18)$ & $27,37(0,93)$ & $61,67(4,15)$ & $3,06(0,43)$ & $16,30(0,96)$ \\
\hline $180^{\circ} \mathrm{C}-3 \mathrm{~h}$ & $71,95(1,22)$ & $6,91(0,31)$ & $28,46(0,26)$ & $61,95(0,84)$ & $3,02(0,28)$ & $16,42(0,40)$ \\
\hline $180^{\circ} \mathrm{C}-5 \mathrm{~h}$ & $67,92(0,56)$ & $7,73(0,15)$ & $29,55(0,20)$ & $63,43(1,27)$ & $4,44(0,48)$ & $18,83(0,98)$ \\
\hline $180{ }^{\circ} \mathrm{C}-7 \mathrm{~h}$ & $61,33(0,64)$ & $8,94(0,47)$ & $27,22(0,42)$ & $61,03(1,41)$ & $4,38(0,22)$ & $18,00(0,39)$ \\
\hline $200{ }^{\circ} \mathrm{C}-3 \mathrm{~h}$ & $56,26(0,96)$ & $8,97(0,45)$ & $24,87(0,88)$ & $60,10(0,97)$ & $3,80(0,47)$ & $17,72(0,77)$ \\
\hline $200{ }^{\circ} \mathrm{C}-5 \mathrm{~h}$ & $43,18(1,35)$ & $7,81(0,55)$ & $16,63(1,05)$ & $55,10(1,66)$ & $5,55(0,38)$ & $17,40(0,97)$ \\
\hline $200^{\circ} \mathrm{C}-7 \mathrm{~h}$ & $39,02(0,52)$ & $7,94(0,48)$ & $14,24(0,59)$ & $51,85(1,36)$ & $5,93(0,19)$ & $17,08(0,35)$ \\
\hline
\end{tabular}




\section{Black Pine}

Table 3: Mean values of color coefficients $\left(L^{*}, a^{*}, b^{*}\right)$ of surface roughness of thermally modified and unmodified (UM) black pine boards before and after exposure to outdoor conditions.

\begin{tabular}{|c|c|c|c|c|c|c|}
\hline Treatment & $\Delta L^{*}$ & $\Delta a^{*}$ & $\Delta b^{*}$ & $\Delta E$ & $C$ & $\Delta C$ \\
\hline $\mathrm{UM}$ & $-16,39(4,13)$ & $-2,43(0,51)$ & $-11,07(1,55)$ & $19,97(4,17)$ & $16,59(1,03)$ & $-11,33(1,59)$ \\
\hline $180^{\circ} \mathrm{C}-3 \mathrm{~h}$ & $-10,00(1,83)$ & $-3,88(0,55)$ & $-12,04(0,55)$ & $16,12(0,71)$ & $16,69(0,43)$ & $-12,59(0,62)$ \\
\hline $180{ }^{\circ} \mathrm{C}-5 \mathrm{~h}$ & $-4,50(1,09)$ & $-3,29(0,53)$ & $-10,73(1,08)$ & $12,09(1,16)$ & $19,34(1,06)$ & $-11,20(1,15)$ \\
\hline $180^{\circ} \mathrm{C}-7 \mathrm{~h}$ & $-0,30(1,36)$ & $-4,55(0,60)$ & $-9,22(0,39)$ & $10,29(0,67)$ & $18,52(0,41)$ & $-10,13(0,53)$ \\
\hline $200{ }^{\circ} \mathrm{C}-3 \mathrm{~h}$ & $3,83(1,02)$ & $-5,17(0,27)$ & $-7,15(0,41)$ & $9,62(0,67)$ & $18,13(0,84)$ & $-8,31(0,45)$ \\
\hline $200^{\circ} \mathrm{C}-5 \mathrm{~h}$ & $11,92(1,20)$ & $-2,26(0,44)$ & $0,76(0,83)$ & $12,16(1,24)$ & $18,26(1,01)$ & $-0,12(0,78)$ \\
\hline $200{ }^{\circ} \mathrm{C}-7 \mathrm{~h}$ & $12,83(1,09)$ & $-2,00(0,54)$ & $2,84(0,53)$ & $13,29(1,05)$ & $18,08(0,37)$ & $1,78(0,68)$ \\
\hline
\end{tabular}

Standard deviation values in parentheses.

According to statistical analysis results, $L^{*}$ values of the pine boards did not present statistically significant differences, except for the case of the two most intensive treatments $\left(200{ }^{\circ} \mathrm{C}-5 \mathrm{~h}\right.$ and $\left.7 \mathrm{~h}\right)$, which do not differ from each other, but differed significantly from all the other treatments values. Regarding the values of the index $a^{*}$, they all appeared to be statistically significant one another, except for the case between the mildest treatment $\left(180{ }^{\circ} \mathrm{C}-3 \mathrm{~h}\right)$ and control. Similar values were recorded by the boards treated at $180{ }^{\circ} \mathrm{C}-5 \mathrm{~h}, 180$ ${ }^{\circ} \mathrm{C}-7 \mathrm{~h}$ and $200{ }^{\circ} \mathrm{C}-3 \mathrm{~h}$. Finally, the two most intensive treatments $\left(200^{\circ} \mathrm{C}-5 \mathrm{~h}\right.$ and $\left.7 \mathrm{~h}\right)$ did not present a statistically significant difference one another. The values of $b^{*}$ did not differ significantly, except for the case of control and the boards treated at $180{ }^{\circ} \mathrm{C}-3 \mathrm{~h}$ that differed from the more intensive treatments $\left(180{ }^{\circ} \mathrm{C}-5 \mathrm{~h}\right.$ and $7 \mathrm{~h}$ ). Additionally, the value of the board treated at $180^{\circ} \mathrm{C}-5 \mathrm{~h}$ appeared to differ significantly from the respective value of the most intensive treatment.

Table 4: Mean color change values of thermally modified and unmodified (UM) black pine after 100-day outdoors exposure.

\begin{tabular}{|c|c|c|c|c|c|c|}
\hline Treatment & $\Delta L^{*}$ & $\Delta a^{*}$ & $\Delta b^{*}$ & $\Delta E$ & $C$ & $\Delta C$ \\
\hline $\mathrm{UM}$ & $-16,39(4,13)$ & $-2,43(0,51)$ & $-11,07(1,55)$ & $19,97(4,17)$ & $16,59(1,03)$ & $-11,33(1,59)$ \\
\hline $180^{\circ} \mathrm{C}-3 \mathrm{~h}$ & $-10,00(1,83)$ & $-3,88(0,55)$ & $-12,04(0,55)$ & $16,12(0,71)$ & $16,69(0,43)$ & $-12,59(0,62)$ \\
\hline $180^{\circ} \mathrm{C}-5 \mathrm{~h}$ & $-4,50(1,09)$ & $-3,29(0,53)$ & $-10,73(1,08)$ & $12,09(1,16)$ & $19,34(1,06)$ & $-11,20(1,15)$ \\
\hline $180^{\circ} \mathrm{C}-7 \mathrm{~h}$ & $-0,30(1,36)$ & $-4,55(0,60)$ & $-9,22(0,39)$ & $10,29(0,67)$ & $18,52(0,41)$ & $-10,13(0,53)$ \\
\hline $200{ }^{\circ} \mathrm{C}-3 \mathrm{~h}$ & $3,83(1,02)$ & $-5,17(0,27)$ & $-7,15(0,41)$ & $9,62(0,67)$ & $18,13(0,84)$ & $-8,31(0,45)$ \\
\hline $200^{\circ} \mathrm{C}-5 \mathrm{~h}$ & $11,92(1,20)$ & $-2,26(0,44)$ & $0,76(0,83)$ & $12,16(1,24)$ & $18,26(1,01)$ & $-0,12(0,78)$ \\
\hline $200{ }^{\circ} \mathrm{C}-7 \mathrm{~h}$ & $12,83(1,09)$ & $-2,00(0,54)$ & $2,84(0,53)$ & $13,29(1,05)$ & $18,08(0,37)$ & $1,78(0,68)$ \\
\hline
\end{tabular}

Standard deviation values in parentheses.

\section{Surface roughness change}

\section{Poplar}

The measurement of the roughness parameters on the radial surface of poplar after the 100-day exposure outdoors revealed a higher degree of roughness for all the boards, compared to the respective values prior to the exposure (Figure 10). The relatively mild heat treatments $\left(180{ }^{\circ} \mathrm{C}-3 \mathrm{~h}\right.$ and $5 \mathrm{~h}, 200^{\circ} \mathrm{C}-3 \mathrm{~h}$ and $5 \mathrm{~h}$ ) slightly kept the roughness values at lower levels, compared to the control and 7-hour treated boards that presented higher roughness levels. The mildest treatment $\left(180^{\circ} \mathrm{C}-3\right.$ hours $)$ decreased the roughness index $R a$ by 17,87 
$\%$ and the $R z$ index by $14 \%$, while the subsequent treatment $\left(180{ }^{\circ} \mathrm{C}-5 \mathrm{~h}\right)$ slightly reduced $R a$ by $5,36 \%$ and $R z$ by $3,88 \%$, compared to unmodified wood. Thermal treatments of $200{ }^{\circ} \mathrm{C}$ for 3 and 5 hours decreased the $R a$ index by $15,05 \%$ and $4,26 \%$, respectively, and the $R z$ by $8,50 \%$ and $2,94 \%$, respectively, compared to control levels. Finally, treatments of 7 hours and temperatures of $180{ }^{\circ} \mathrm{C}$ and $200{ }^{\circ} \mathrm{C}$ showed an increased $R a$ index by $11,14 \%$ and $0,40 \%$, respectively, compared to control and also a 7,74 \% increase in the $R z$ and 2,38 $\%$, respectively. As a result, thermal treatments lasting more than 5 hours seemed to fail in the protection of wood from the action of climatic factors that contribute to the creation of greater surface roughness.

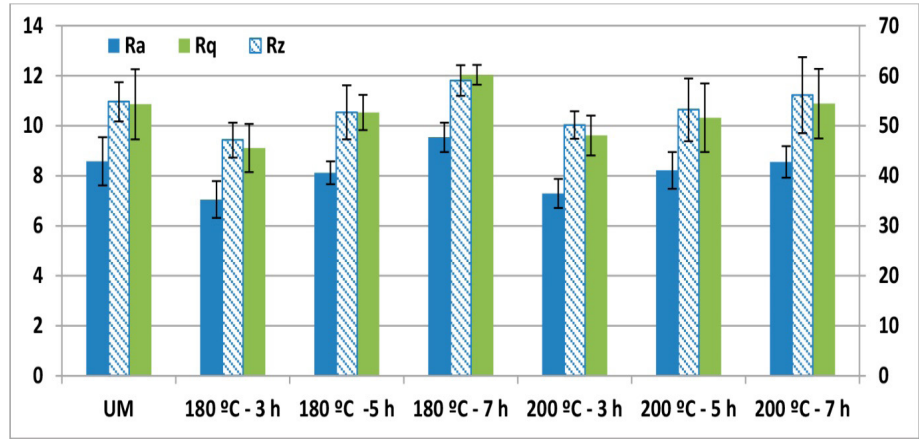

Figure 10: Progress of the mean values of the three roughness parameters $(R a, R z, R q)$ of the unmodified (UM) and thermally modified poplar boards after 100 - day exposure to external conditions (the secondary vertical axe corresponds to $R z$ values).

$R a$ values did not show any statistically significant differences, except for the following cases: the value of the control was found to be significantly different from the value of the mildest treatment $\left(180{ }^{\circ} \mathrm{C}-3 \mathrm{~h}\right)$. Additionally, the value of the board of the mildest treatment was found significantly different from the respective value of longer treatments $\left(180{ }^{\circ} \mathrm{C}-7 \mathrm{~h}, 200{ }^{\circ} \mathrm{C}-7 \mathrm{~h}\right)$. Finally, a statistically significant difference was found between the values of the boards treated at $180^{\circ} \mathrm{C}-7 \mathrm{~h}$ and $200{ }^{\circ} \mathrm{C}-3 \mathrm{~h}$. Regarding the $R z$ values, the only statistically significant difference found was between the $180{ }^{\circ} \mathrm{C}-3 \mathrm{~h}$ and $180{ }^{\circ} \mathrm{C}-7 \mathrm{~h}$ treatment. Regarding $R q$ values, significant differences were found only between $180{ }^{\circ} \mathrm{C}-7 \mathrm{~h}, 180{ }^{\circ} \mathrm{C}-3 \mathrm{~h}$ and $200{ }^{\circ} \mathrm{C}-3$ h.

\section{Black pine}

The roughness indexes on the surface of all the black pine boards, after the exposure, were found increased compared to the respective values prior to the exposure. The mildest and shortest treatments $\left(180^{\circ} \mathrm{C}-3 \mathrm{~h}, 180\right.$ ${ }^{\circ} \mathrm{C}-5 \mathrm{~h}, 200^{\circ} \mathrm{C}-3 \mathrm{~h}$ ) appeared to shield the wood surface slightly from the action of climatic factors that tend to make it rougher (Figure 11).

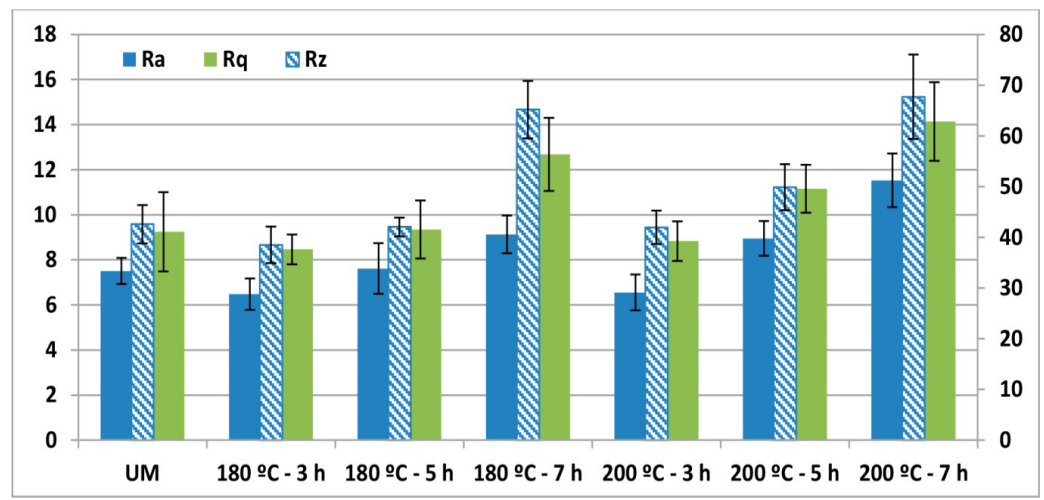

Figure 11: Progress of the mean values of the three roughness parameters $(R a, R z, R q)$ of the unmodified (UM) and thermally modified black pine boards after 100 - day exposure to external conditions (the secondary vertical axe corresponds to $R z$ values).

The control boards and the boards heat-treated at more intensive treatments exhibited a higher degree of roughness. Specifically, the mildest heat treatment $\left(180^{\circ} \mathrm{C}-3 \mathrm{~h}\right)$ reduced the $R a$ roughness index by $13,67 \%$ 
and the $R z$ index by $9,56 \%$, while the subsequent treatment $\left(180{ }^{\circ} \mathrm{C}-5 \mathrm{~h}\right)$ slightly increased the $R a$ by 1,47 $\%$ and reduced $R z$ by $1,25 \%$. Treatments of higher intensity increased $R a$ by $19,24 \%$ and $53,57 \%$ and $R z$ by $17,16 \%$ and $59,02 \%$, with the exception of short treatment at $200{ }^{\circ} \mathrm{C}$, which decreased $R a$ by $12,71 \%$ and $R z$ by $1,46 \%$. Therefore, heat treatments of duration over 3 hours did not protect the wood surface from the action of climatic factors and from increasing its roughness.

According to the results of the statistical analysis, there were no statistically significant differences between the $R a$ values except in the following cases: The last treatment $\left(200^{\circ} \mathrm{C}-7 \mathrm{~h}\right)$ appeared to be significantly different from all other categories values. The mildest treatment $\left(180^{\circ} \mathrm{C}-3 \mathrm{~h}\right)$ was found to be statistically significantly different from the same temperature and 7 hour handling as well as the $200{ }^{\circ} \mathrm{C}-5 \mathrm{~h}$ treatment. Also, the temperature treatment of $200^{\circ} \mathrm{C}$ and 3 hours duration is significantly different from the previous treatment $\left(180^{\circ} \mathrm{C}-7 \mathrm{~h}\right)$, but also from the other treatments of the same temperature $\left(200{ }^{\circ} \mathrm{C}-5 \mathrm{~h}\right.$ and $7 \mathrm{~h}$ ). Regarding the values of the $R z$ index, no statistically significant differences were found between the values except for the following cases: longer treatments $\left(180^{\circ} \mathrm{C}-7 \mathrm{~h}\right.$ and $\left.200{ }^{\circ} \mathrm{C}-7 \mathrm{~h}\right)$ were found to be different from all other values, but not significantly different from each other. Finally, the mildest treatment $\left(180{ }^{\circ} \mathrm{C}-3 \mathrm{~h}\right)$ showed a significant difference compared to $200{ }^{\circ} \mathrm{C}-5 \mathrm{~h}$. The same differences were recorded between the values of $R q$.

According to the results of both species, the duration of over 5 hours, of thermal treatment (under the specified conditions), presented a negative impact on the integrity of wood tissue and smoothness of the surface, probably attributed to the changes induced by the thermal treatment in the chemical components and morphological characteristics of wood (Kamperidou 2019). The loss of volatile extractives, hemicelluloses and part of amorphous cellulose, due to the thermal treatment, contribute to the reduction of wood density and therefore, may increase the surface roughness. Additionally, the thermal treatment induces a cellulose crystallization increase, lignin network condensation, through crosslinking reactions, that makes the material more brittle (Hill 2006), which may also contribute to a higher roughness of the wood surface. In this sense, the wood tissue is weakened, due to the strong thermal degradation it has undergone during thermal modification, and becomes more susceptible to the destructive impact of climatic factors acting in the exterior environment. Therefore, more cracks and fibers delamination appear in the surface, while the phenomenon of wood surface corrosion becomes even more profound, resulting in a surface roughness increase.

\section{CONCLUSIONS}

After a 100 - day exposure outdoors of pine and poplar boards, a similar degree of discoloration towards gray color was observed on the control boards and the thermally modified boards, probably due to the leaching of the water-soluble extracts and hemicelluloses degradation. The wood of both species obtained new checks and cracks and signs of mold and fungal infestation, more apparent in the control and the most intensive treatments of $200{ }^{\circ} \mathrm{C}$, with poplar boards to demonstrate more dense defects patterns on their surfaces (especially in control and intensively treated boards), compared to black pine boards. As a result, heat treatment appeared to contribute only to a small extent to the protection of poplar or pine wood against aging factors, with mild treatments of $180^{\circ} \mathrm{C}$ to have been proved as more advantageous to the weathering performance of wood. Specifically, poplar and pine boards were discolored to such an extent that they all had a similar color to that of the control ones, as assessed macroscopically and microscopically and also evidenced by the course of the color indexes $L^{*}, a^{*}$ and $b^{*}$ of the poplar and pine surfaces, revealing that heat treatment failed to protect the color of the boards.

After the exposure, the roughness of all the boards of both species was higher than the pre-exposure respective values. The milder treatments acted protectively on wood, reducing the roughness levels by $17,87 \%$ for poplar and 13,67\% for pine wood, compared to control, whereas the control and most intensive treatments $\left(200{ }^{\circ} \mathrm{C}\right)$ exhibited higher roughness values.

Thermal treatment enhanced crucial properties such as biological durability and dimensional stability, but it did not adequately protect the wood from the weathering effect of biotic and abiotic factors in outdoor environment. Nevertheless, the wood of both species modified at short-term heat treatments exhibited improved properties compared to unmodified wood, and if we take into account also the fact that in the milder treatments there was not any mechanical strength loss, it can be concluded that these materials could be potentially utilized in applications where structures are not continuously and directly exposed to aging factors, for example under shelter applications (wood frames among others) or after the application of a combination 
of heat and surface modification with protective preservatives.

\section{REFERENCES}

ASTM. 2016. Standard Practice for Calculation of Color Tolerances and Color Differences from Instrumentally Measured Color Coordinates. ASTM D2244-16. 2016. ASTM International: West Conshohocken, PA, USA.

Ates, S.; Akyildiz, M.H.; Özdemir, H.; Gumuskaya, E. 2010. Technological and chemical properties of chestnut (Castanea sativa Mill.) wood after heat treatment. Rom Biotechnol Lett 15(1): 4949-4958. http://earsiv.kastamonu.edu.tr:8080/jspui/handle/123456789/633

Awoyemi, L.; Jarvis, M.C.; Hapca, A. 2009. Effects of preboiling on the acidity and strength properties of heat-treated wood. Wood Sci Technol 43: 97-103. https://link.springer.com/article/10.1007/s00226-008$0231-4$

Bak, M.; Nemeth, R. 2012. Changes in swelling properties and moisture uptake rate of oil-heat-treated poplar (Populus $\times$ euramericana cv. Pannónia) wood. BioResources 7(4): 5128-5137. https://bioresources.cnr. ncsu.edu/resources/changes-in-swelling-properties-and-moisture-uptake-rate-of-oil-heat-treated-poplar-populus-X-euramericana-cv-pannonia-wood/

Budakci, M.; Cemil Ilce, A.; Gurleyen, T.; Utar, M. 2013. Determination of the surface roughness of Heat-treated wood materials planed by the cutters of the horizontal milling machine. BioResources 8(3): 3189-3199. https://bioresources.cnr.ncsu.edu/resources/determination-of-the-surface-roughness-of-heat-treated-wood-materials-planed-by-the-cutters-of-a-horizontal-milling-machine/

CEN. 2019. Paints and varnishes. Coating materials and coating systems for exterior wood. Natural weathering test. CEN. EN 927-3. 2019. Brussels, Belgium.

DIN. 2012. Colorimetry - Part 3: CIE tristimulus values. DIN EN ISO 11664-3. 2012. Berlin, Germany.

Feist, C.W.; Sell, J. 1987. Weathering behavior of dimensionally stabilized wood treated by heating under pressure of nitrogen gas. Wood and Fiber Science 19(2): 183-195. https://wfs.swst.org/index.php/wfs/article/ view/958/958

Garcia, R.A.; Lopes, J.; do Nascimento, A.M.; Latorraca J.V. 2014. Color stability of weathered heat-treated teak wood. Maderas-Cienc Tecnol 16(4): 453-462. https://scielo.conicyt.cl/scielo.php?pid=S0718 $-221 \mathrm{X} 2014000400008 \&$ script=sci_arttext

Gündüz, G.; Korkut, S.; Korkut, D.S. 2008. The effects of heat treatment on physical and technological properties and surface roughness of Camiyanı Black Pine (Pinus nigra Arn. subsp. pallasiana var. pallasiana) wood. Bioresour Technol 99: 2275-2280. https://doi.org/10.1016/j.biortech.2007.05.015

Hill, C. 2006. Wood Modification, Chemical, Thermal and other processes. John Wiley \& Sons Ltd: The Átreium, Southern Gate, Chichester, UK. ISBN: 978-0-470-02172-9, 260 pp.

ISO. 1997. Geometrical Product Specifications (GPS) - Surface texture: Profile method - Terms, definitions and surface texture parameters. ISO 4287:1997. ISO: Geneva, Switzerland.

ISO. 2014. Physical and Mechanical Properties of Wood-Test Methods for Small Clear Wood Specimens-Part 1: Determination of Moisture Content for Physical and Mechanical Tests. ISO 13061-1. 2014. ISO: Geneva, Switzerland.

ISO. 2014. Physical and Mechanical Properties of Wood-Test Methods for Small ClearWood Specimens - Part 2: Determination of Density For Physical and Mechanical Tests. ISO 13061-2. 2014. ISO: Geneva, Switzerland.

ISO. 2019. Wood - Sampling Methods and General Requirements for Physical And Mechanical Testing of Small Clear Wood Specimens. ISO 3129. 2019. ISO: Geneva, Switzerland.

ISO. 2016. Paints and varnishes - Evaluation of degradation of coatings - Designation of quantity and size 
of defects, and of intensity of uniform changes in appearance - Part 1: General introduction and designation system. ISO 4628-1. 2016. ISO: Geneva, Switzerland.

Kamperidou, V.; Barboutis, I. 2017. Mechanical Performance of Thermally Modified Black Pine (Pinus nigra L.) Wood. Electronic Journal of Polish Agricultural Universities 20: 7-13. https://doi.org/10.30825/5. ejpau.20.2017.20.1

Kamperidou, V.; Barboutis, I. 2018. Changes in hygroscopic properties of poplar and black pine induced by thermal treatment. PRO Ligno 14(4): 57-64. http://www.proligno.ro/en/articles/2018/4/KAMPERIDOU.pdf

Kamperidou, V.; Barboutis, I.; Vasileiou, V. 2013. Hygroscopicity of thermally modified poplar (Populus sp.) wood. PRO Ligno 9(4): 664-669. http://www.proligno.ro/en/articles/2013/4/Kamperidou_final. pdf

Kamperidou, V. 2019. The biological durability of thermally- and chemically-modified black pine and poplar wood against basidiomycetes and mold action. Forests 10(12): 1111. https://doi.org/10.3390/f10121111

Korkut, S.; Budakci, M. 2010. The effects of high-temperature heat-treatment on physical properties and surface roughness of Rowan (Sorbus aucuparia L.) wood. Wood Research 55(1): 67-78. http://www.woodresearch.sk/wr/201001/08.pdf

Mburu, F.; Dumarcay, S.; Bocquet, J.F.; Petrissans, M.; Gerardin, P. 2008. Effect of chemical modifications caused by heat treatment on mechanical properties of Grevillea robusta wood. Polym Degrad Stabil 93(2): 401-405. https://doi.org/10.1016/j.polymdegradstab.2007.11.017

Mummery, L. 1992. Surface texture analysis. The handbook. Hommelwerke: GmbH, Thyssen, Muhlhausen, Germany, 106 p.

Rajković, V.J.; Miklečić, J. 2012. New insights into improving the colour stability of thermally modified wood exposed to UV-light. In International Conference of Ambienta 2012, Wood is good - With knowledge and technology to a competitive forestry and wood technology sector Grbac, Ivica, editor(s). Zagreb: Faculty of Forestry, University of Zagreb, 41-47.

Sandberg, D. 1999. Weathering of radial and tangential wood surfaces of pine and spruce. Holzforschung 53(4): 355-364. https://doi.org/10.1515/HF.1999.059

Schneid, E.; de Cademartori, P.H.G.; Gatto, D. 2014. The effect of thermal treatment on physical and mechanical properties of Luehea divaricata hardwood. Maderas-Cienc Tecnol 16 (4): 413-422. https://doi.org/10.4067/S0718-221X2014005000033

Stumbo, D.A. 1963. Surface texture, measuring methods. Forest Prod J 12(7): 299-303.

Yildiz, S.; Yildiz, U.; Tomak, E. 2011. The effects of natural weathering on the properties of heat-treated alder wood. BioResources 6(3): 2504-2521. https://bioresources.cnr.ncsu.edu/resources/the-effects-of-naturalweathering-on-the-properties-of-heat-treated-alder-wood/ 